\title{
The influence of digital technology on the cultural evolution of a city's monumental icons
}

\author{
G.A. Prahara \\ Telkom University, Bandung, Indonesia \\ M.Y. Suhairi \\ University Computer Indonesia, Bandung, Indonesia
}

\begin{abstract}
Sculptures serve as a symbolic reflection of a spirit that contains philosophical, historical, and aesthetic elements. Digital technology makes it easy to replicate and reduplicate, as well as speed up, the process of working on the pre-production process and the production of threedimensionally built objects. A society's misinterpretation turned the monumentally built objects in Bandung into a decorating tool for the city, yet visually borrowing form from cultural objects with philosophical value. The method used in this study was ethnography-descriptive observations on three-dimensional spatial objects to explore relationships between the physical form of the objects with cultural philosophical beliefs of today's society. There has been a decrease in philosophical significance because of cultural objects' replication through the use of digital technology.
\end{abstract}

Keywords: digital technology, spatial objects, cultural symbol

\section{INTRODUCTION}

Bandung is a historic city, the center of West Java's cultural development, where various historical events became iconic symbols. Heritage buildings have become symbols of modern cultural acculturation based on historical narratives currently used as symbols of civilization. In Bandung, there are objects built with a spatial approach such as statues, monuments, buildings, and symbols. The current municipality uses duplicated cultural objects in form of figures, typography, and cultural symbols in public areas in Bandung. Bandung's green open space was revitalized into a friendly open park with a community's physical activity and became a comfortable place to interact.

Bandung City Square was revitalized into a playground for children and families with synthetic grass flooring. Spatial typography serves as identity in an open space such as a city park or identification of a location. The Siliwangi Tiger statues, facing the four wind directions, became decorators at several crossroads in Bandung. The Kujang (traditional weapon) symbol was built as part of border signs on street gates as well as an iconic element of the philosophical character of West Java society. Kujang monuments in several places stand as a reminder of the Sundanese people's ancestors related to the Padjadjaran Kingdom. All objects are imitations or artificial replications of their original form functioning as aesthetic elements of the city.

The development of digital technology, especially three-dimensional printing presses, revolutionized the industry's design and manufacturing. The creation of a prototype in three-dimensional design takes a short time, as the capabilities of the three-dimensional print machine are advanced. Solid materials of both color and type can be cheap and easy to make into a prototype according to the design on a digital computer (White Clouds 2019).

The development of production techniques and tools based on digital technology can answer design needs including laser cutting tools for large scale objects, where shapes can be printed on metal at the desired scale. Materials are increasingly flexible so that they can be easily transformed 
into any statues or monumental objects. It gives ease of replicating objects into mimesis on spatial objects in public spaces. The artificial nature found in spatial objects in public spaces create a new interpretation by the city community. The purpose of this research is to explore the shift of symbolic significance of spatial built visualization using digital technology.

Research on public spaces and the growing monumental build-up and its challenges to public art is a comparison of the changing society in living the art of public spaces (Remesar 2005). Public pedagogy is part of the process of a learning society in public spaces through public art (Schuermans et al. 2012). Monuments function as witnesses to cultural identity (Johnson 2002). The statue as an urban monument is the basis of its regional culture (Jixin 2019).

In other research, it is stated that the current spatial build in public spaces has a relationship with the lifestyle of urban society, namely as a tool of individual and communal expression as a universal part (Nursaiman 2012). The research only discusses spatial stimulate functions that are more associated with people's emotional approaches, especially on lifestyles in public spaces. Other research on spatial builds and public spaces were also discussed in Aulia (2014) that viewed the space of the interior and some technical standards that should be considered in its design.

Another related research with a different study object is the research on monumental spacial builds in tourist areas in Yogyakarta. Many typographies are applied in public spaces as identity as well as branding but less emotive from psychosocial aspect, especially typographic approached with the value of a region (Noordyanto 2017). The study emphasizes the branding elements that can affect perception in public spaces. In other research it was also discussed that the use of public spaces as gathering places for communities at the thematic park in Bandung (Ilmiajayanti 2015).

This research discovers a spatial build development in the monumental ornaments of the city that are used as a form of decorative elements, a marker of cultural identity, which uses digital technology. It is also determined to deepen the influence of these objects on the direction of a symbolic meaning desired by the proponents on the development of an urban society.

\section{METHOD}

In this research, Barthes' semiological theory was applied to reveal the meaning of the artificial monumental symbolic object. Ethnographic studies were used as a benchmark for text narrative analysis contained in an object. Advanced analysis was done by linking text with a micro understanding of the community related to symbols contained in each object of inclusion (Piliang 2003). It implies that the meaning begins with an understanding of the denotative conception continued by knowing its connotative meaning.

The research was done in the qualitative descriptive method with semiological disclosure of meaning through the analysis of content on awakened objects. It found meaningful relationships based on narrative structures that have been built up through generations with current artificial replication. Textual analysis of the development of digitalization through technology relates to contemporary styles that are imitations of cultural philosophical traditions. The data was collected through an object's deep understanding and community interpretation based on the character of the traditional icons.

\section{RESULT AND DISCUSSION}

The city square, once a place used as a dialogue space between the city's stakeholders and citizens, now is the center of crowd and celebration. It is the trigger for changes in function and historical significance of the place. The change in the layout of the square is a sign of the development of social civilization in the city of Bandung (Figure 1).

The Bandung City Square had changed into a modern space. Digital technology plays a role in its design. Its conception today is more open and heterogeneous. Restoration was carried out by the government, functionally and structurally, by designing the square for the people (Figure 2). 

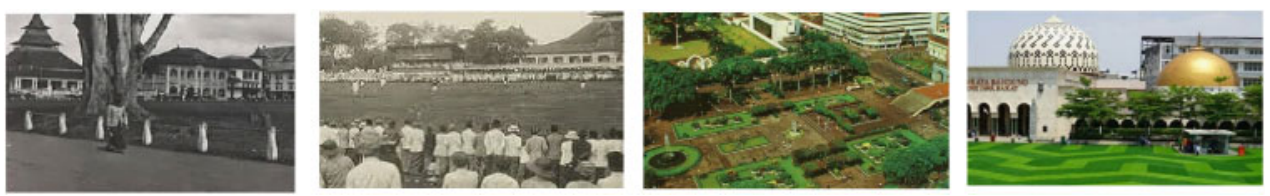

Figure 1. Journey of Bandung City Hall Square. (Source: Ichan 2015; Humas Bandung.go.id).

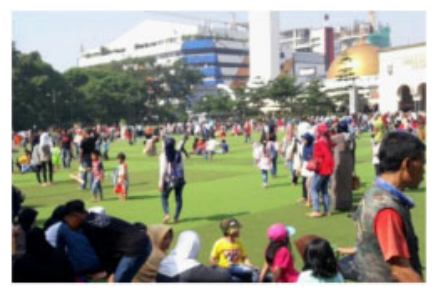

Figure 2. Bandung City Hall nowadays. (Source: Tribun Jabar.com).
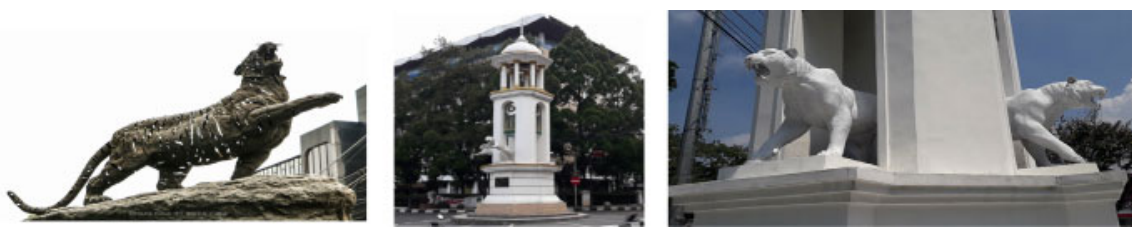

Figure 3. Monument of Siliwangi Tiger. (Source: Bandung Public Art Archive 1990; TribunJabar 2018).

The current square is a playground for families and children, citizens, and tourists. The sacred value of the square faded into a playground. The text of the square that presents is a form of denotation of expression. Digital technology is very instrumental in the formation of green synthetic grass patterns that attract visitors to take selfies and become a scattering point in cyberspace.

People know the narrative about the Sundanese royal lineage Padjadjaran whose king was named Prabu Siliwangi. In addition to its pedigree, people also know about the mythical story related to the Tiger of Siliwangi. This cultural narrative remains preserved as a symbol of the spirit of patriotism. Both the tiger and king names are used as the name and symbol of the West Java military unit (Figure 3).

Maung Siliwangi (Siliwangi Tiger) figures are the result of technological advances in digital and resin printing methods, making it easy to replicate and duplicate the object. There are statues of four identical tigers pointing to four opposite directions inside a classic art deco gazebo monument. Tiger characters were duplicated. Even though they look identical, meaningfully there was a shift into an ornamental figure that serves only as an empty monument. This means that despite borrowing the symbol of the Siliwangi Tiger, it fails to foster a cultural philosophical awareness to the public (Figure 4).

Kujang is a traditional weapon typical of West Java that is a symbol of the war readiness of Padjadjaran soldiers. Kujang is also a symbol of the agrarian Sundanese community. It is currently being used as a marker pole on the entrance at some point in the city. Artificially this Kujang character is made to point upward, standing upright like a fire, with a golden color so that it looks contrasting from a distance.

Laser cutting technology that can cut metal or steel on a large scale has a role in duplication of the Kujang monument. The symbol of Kujang has become a space element as the street decorator as well as the street marker. Its meaning slowly shifting into a border sign on the entrance of the 


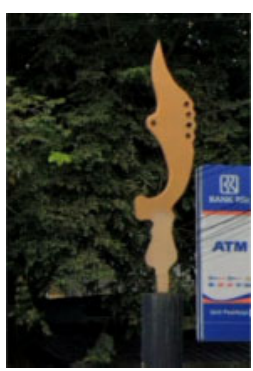

Figure 4. Kujang monument, Google street view 2019.
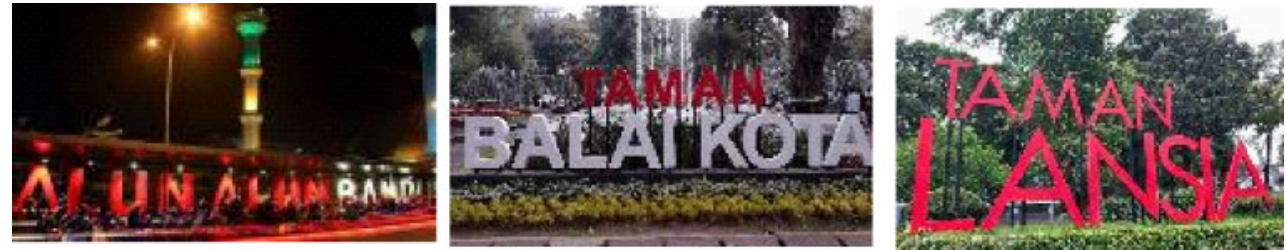

Figure 5. Typography spacial as public park identity. (Source: Pemprov Jabar 2017).

street. Philosophical objects that changed its function obscure the meaning of the symbols. This caused society to interpretate the sign as only a passive peg or pillar.

Spatial typography is widely used as an identity marker for a location. However, there are two strong perceptions of typography: the context of the typeface and the message in which the text was formed and presented (Romano 2012). Typography is one of the relative visual elements, analogized as a dish that has different flavors according to the taste and type of food (Saltz 2013) (Figure 5).

With the conception of similar-looking letter symbols that are the result of digital technology that makes it easy in the pre-production and production process, making the same typeface and character of letters do not represent the characteristics of the location it is written for. The typeface used is an international style with sans serif type so that it looks modern to refract society from the meaning of the name and location that it shows.

A monument is "a building derived from human creation as a form of reflection of the past or something that can be remembered by future generations" (Riegl 1903, in Panico 2016). The symbol of the building generally has abstract values and meanings that are traditionally believed and used as the spirit and motivation of society. This research shows the value of a philosophical substance that shifts. It is the results of imitations of cultural symbols used as decorators or amplifiers of the city's aesthetic elements through replication using advancement of digital technology. There is a decline in the philosophical meaning of the cultural spirit today's society.

The micro-aspect of Bandung's society toward the text in the form of artificialization of monumental spatial symbols states a form of government stimulus to beautify and make an impression of the city's tingle. Aspects of the city's aesthetic reinforcement are the main factors of the denotative forces that are formed. The use of symbols in city halls, intersected with macro text narratives in the form of symbolic narratives of cultural philosophy, is revered into the middle ground as an entrance to the symbolic capital of the people. Societies, with cultural changes that occur, make connotative significance meaningless. The interpretation of existing objects become denotative in a pragmatic way. The concept comes as digital technology develops. It also facilitates and accelerates the formation of identical imitations of the same nature. The concept obscures the meaning of macro symbolic connotations into a temporary denotative structure because it is easily obsolete or damaged due to weather or time. 
The micro text meaning of the Bandung people began to reduce over time in the social and cultural capital of the Sundanese people. The change of symbolic meaning relates to the change in the social, economic, political, and cultural capital of Bandung people. Although it does not change the conception of the macro narrative toward the object's ideal meaning, the construction's formation in public spaces through imitative artificial shorting results in a change in the social interpretation of the city community.

\section{CONCLUSION}

Built spatial monuments, that stand firmly in the middle of the city, prioritize the underlying meaning related to philosophical, ideological, historical, and aesthetic values in society. Today's advances in digital technology have transformed the work generally done through an artist's craftmanship approach into a digitally conceptualized approach through urban governance planning. Technology becomes an imitation machine that can produce symbolic objects of the city more perfectly and precisely as decorative elements, capable of replacing the emptiness of space in the city. However, without care, it can gradually erode the cultural, historical, and philosophical significance of a city symbolic spaces into just artificially plastic construction.

\section{REFERENCES}

Alfrey, S. L. 2013. Occupy Plop Art Public Sculpture as Site of Antagonism. Thesis. University of Illnois at Chicago, 26(4).

Drout, M. D. C. 2007. A Meme-Based Approach to Oral Traditional Theory. Oral Tradition, 21(2):269-294. https://doi.org/10.1353/ort.2007.0002

Freska Ilmiajayanti, D. I. K. D. 2015. Persepsi Pengguna Taman Tematik Kota Bandung Terhadap Aksesibilitas dan Pemanfaatannya. 1(1):21-30. https://doi.org/10.14710/ruang.1.1.21-30

Jaganath, T. 2018. The Importance of Public Spaces. medium.com. https://medium.com/@thejas009/theimportance-of-public-spaces-5bb49ba6c000. Project for Public Space.

Jhonson, N. C. 2002. Maping monuments: the shaping of public space and cultural identities. Journal Visual Communication 1(3):293-296. Queen University, London Thousand Oaks, CA and New Dehli: SAGE Publication.

Jixin, W. 2019. Comparative study of urban sculpture base on regional Culture. 2nd Conference Arts, Linguistics, Literature and Humanisties (ICALLH 2019), Xiamen Academy of Art and Ddesign, Fuzou University, Fujian, Xiamen. UK: Francis Academic Press.

Marsden, P. 2018. Memetics and Social Contagion: Two Sides of the Same Coin? Compiled By Collegiate Professor, University of Maryland University College BobF@RoboticTechnologyInc.com. March.

Noordyanto, N. 2017. Studi Tipografi Kawasan Di Yogyakarta. DeKaVe 9(1):65-84. https://doi.org/10.24821/ dkv.v9i1.1659

Nursaiman, D. 2012. Relasi Enviromental Typography, Public Space Dan Gaya Hidup. Visualita 4(1):42-57. https://doi.org/10.33375/vslt.v4i1.1110

Panico, Mario. 2016. The Meanings of Monuments and Memorials: Towards a Semiotic Approach. Punctum, 2(1):28-46, 2016.

Ruki, U. A. and Nediari, A. 2014. Penerapan Tipografi dalam Sistem Signage pada Interior Ruang Publik. 5(9):822-832.

Remesar, A. (Ed). 2005. Urban Regeneration A challenge for Public Art. University of Barcelona, Monografies, Psico Socio Ambientals.

Schuermans, N., Loopman, M., Vandenabeele, J. 2012. Public Space, Public Arts and Public Pedagogic. Journal Social and Cultural Geography.

Stott, T. (2019). Operable abstraction: How toys changed the logic of modern sculpture. Sculpture Journal 28(2): 161-173. https://doi.org/10.3828/sj.2019.28.2.2

Velikovsky, J.T. 2018. The Holon/Parton Theory of the Unit of Culture (or the Meme, and Narreme). Technology Adoption and Social Issues, Koestler 1967: 1590-1627. https://doi.org/10.4018/978-1-5225-5201-7.ch075

White Clouds. 2019. https://www.whiteclouds.com/large-letters/fineartamerica2020 https://fineartamerica. $\mathrm{com} /$ featured/the-famous-giant-letters-of-amsterdam-georgi-djadjarov.html 